\title{
Why Do Consumers Buy Fair Trade Products? An Evolutionary Perspective Using the Theory of Consumption Values
}

\author{
Claudio Pousa ${ }^{1} \&$ Juan Francisco Nuñez ${ }^{2}$ \\ ${ }^{1}$ Faculty of Business Administration, Lakehad University, Thunder Bay, Canada \\ ${ }^{2}$ Faculté d'Administration, Université de Sherbrooke, Sherbrooke, Canada \\ Correspondence: Claudio Pousa, Faculty of Business Administration, Lakehead University, 955 Oliver Rd., \\ Thunder Bay, ON., P7B 5E1, Canada. Tel: 1-807-343-8388. E-mail: cepousa@lakeheadu.ca
}

$\begin{array}{ll}\text { Received: March 3, } 2014 & \text { Accepted: April 7, } 2014 \quad \text { Online Published: May 27, } 2014 \\ \text { doi:10.5539/jms.v4n2p1 } & \text { URL: http://dx.doi.org/10.5539/jms.v4n2p1 }\end{array}$

\begin{abstract}
Fair trade (FT) is a widely recognized and accepted model of exchange for goods and services, which has matured over several decades of evolution. Although Fair Trade products are increasingly important in many markets, research has neither provided a comprehensive framework to analyze this evolution nor provided a rationale that explains why this evolution took place. The purpose of this paper is twofold. First, we aim at integrating the different eras in the evolution of FT into a comprehensive framework that can facilitate the comparison between studies. Second, we aim at explaining this evolution from the perspective of the individual consumer using the Theory of Consumption Values (TCV). We propose that, as the organizational and marketing strategies evolved for FT products, a corresponding evolution at the consumer level took place. This evolution refers to the individual beliefs of the customer who is seeking and perceiving a set of values on FT products. The paper presents an innovative perspective, as well as implications for theory and practice.
\end{abstract}

Keywords: fair trade, sustainability, social responsibility, marketing, theory of consumption values, consumer behaviour, consumer marketing

\section{Introduction}

Fair trade (FT) is a widely recognized and accepted model of exchange of goods and services. This business practice emerged in the late forties as a response to the rigidity of conventional markets. FT has matured over several decades of evolution. Some authors catalogue FT as an "institutionalized" form of trade: a mature social movement that questions and, at the same time, renews traditional economic spheres (Gendron, Basaillon, \& Otero-Rance, 2009). In its very nature, FT is a commercial practice that connects marginalized producers from the south with responsible consumers from the north.

Fair trade has adopted an increased commercial orientation which tends to converge with conventional market practices (Davies, 2007; Doherty, Davies, \& Tranchell, 2012). Nevertheless, the focus, the objectives and the marketing strategies of FT actors have endured considerable transformation during the last seventy years. The early phases of FT were marked by ideological imperatives with the main goal of raising public awareness. This permitted FT a limited growth that was later broadened by the introduction of labelled products in mainstream markets with a shift of goals from ideological to commercial. Increased commercial goals led to standardization and wider distribution. These facts transformed organizational structures and supply chains of FT products. Researchers suggest that FT tends towards increased institutionalization and state recognition (Davies, 2007; Gendron et al., 2009; Renard, 2003). Organizational strategy and marketing objectives for this new era might bear the notions of sustainability, consumer value and responsible consumption.

\subsection{Research Problem}

Despite the importance that Fair Trade products achieved lately, there has been only a small number of published works (mostly case studies) researching their characteristics and evolution. Furthermore, as different geographic markets started to incorporate FT products at different moments and with different enthusiasm, a direct, cross-sectional comparison between markets is not feasible because there is no single analytical framework that could integrate the evolutionary changes in FT markets comprehensively. This makes the comparison between studies difficult and prevents from generalizing learning. 
Moreover, although the description of changes in markets, actors and goals is important from an evolutionary perspective, it is even more important to understand why those changes happened and what the drivers of those changes are. Understanding the reasons why FT markets evolved can help managers identify the stage in FT evolution that their markets are in, as well as the steps that they might take to adapt their strategies to that market evolution.

\subsection{Objectives}

This paper has two objectives. The first one is to develop an integrative framework to understand the sequence of eras in the development of Fair Trade. Building on a review of the most respected authors (Davies, 2007; Doherty et al., 2012; Gendron et al., 2009; Lemay, Favreau, \& Maldidier, 2010) we present the evolution of FT from a general standpoint along its scholarly, known generations, integrating different authors' perspectives into one comprehensive framework. This could be a contribution in itself, because different scholars presented the results of different case studies in different countries and regions (i.e., UK, continental Europe) but without using any unifying framework that would allow for comparisons among the studies. Having a comprehensive framework can allow scholars to situate their research environment into a particular era in the evolution of fair trade, analyze past contexts and predict potential developments.

Our second objective is to provide a rationale for the evolution of Fair Trade in different eras. We build on the Theory of Consumption Values (Seth, Newman, \& Gross, 1991a, 1991b) to understand the evolution of consumers' value perception associated with the FT products available at the different eras of the movement. Understanding consumers' value perception of FT products has strong and immediate significance for practitioners willing to brand, to position and to communicate FT product offerings. The comprehension of the different values sought by consumers, will allow practitioners to define market segments, to refine product lines, to position brands and to define communication campaigns. To that purpose, TCV is a parsimonious theory with a high explanatory and predictive power. This theory constitutes the ideal framework to analyze consumers' value perception.

\subsection{Paper Structure}

In the following section, we present the evolution of Fair Trade and we propose that this evolution can be organized around four eras, each one characterized by specific market structures, players and motivations. Then, we re-interpret this evolution through the lens of the Theory of Consumption Values. Consequently, we identify the different values sought by consumers when purchasing FT products. We summarize our findings in Table 1 which arrays the fair trade commercial periods of development across various managerial axes. In this array, we present the values sought by FT consumers in each historical period of the movement.

By the end of the paper, we present a discussion of our findings in which we identify significant managerial implications. We conclude the paper exploring the limits of our work and offering avenues for future research.

\section{The Evolution of Fair Trade}

Scholarly work on the evolution of FT reveals the existence of three known generations or eras for this movement since its inception to our days. A fourth, hypothesized era is added to the other three to describe the immediate future of the movement, particularly in the most advanced markets of FT. Each of these four eras is characterized by a distinctive focus and a particular form of coordination between participant groups, as well as a particular structure for the marketing and the distribution of FT products.

Different studies, however, established the focus, the actors, the strategies and the time brackets for each era of FT based on the context of their case studies which differ geographically. These facts explain why FT periods have not initiated, transitioned and finalized at the same time in North America, continental Europe or in the United Kingdom. In order to bring more clarity to this text, we have aligned the time periods for improved general understanding, and we have adopted the appellation proposed by Davies (2007) for each of the three eras.

\subsection{The Solidarity Era of Fair Trade}

The solidarity era of fair trade goes from the beginning of FT exchanges (as early as 1940 for some authors, or as late as 1970 for others) and extends until the early nineties. Ideological convictions were the impetus in this era, and it was focused on the process (Nicholls \& Opal, 2005). Profit making and market expansion were not the main goals of the participant organizations in this era. Tallontire (2000) names this period "goodwill selling" in which market development was based on supporting initiatives of cooperation with producers and demonstrating solidarity with marginalized groups. Organizational strategies were underpinned by ideological purposes of raising awareness on issues of the developing world (Davies, 2007). 
The business model linked to this era could be conceptualized as ideological (Giovannucci \& Koekoek, 2003) because it pushed for the establishment of direct trading links with impoverished producers, challenging the rules of traditional international trade. The underlying marketing strategies that can be attributed to this era are those focused on solidarity and development. These strategies emphasized the social aspects of the exchange process, in general, and the social attributes of the producer, in particular. Some examples of the notions mobilized within the marketing strategies in this era are impoverished communities, marginalized and disorganized peasants, difficulty to access international markets, development of autonomy at the producer lever, improvement of direct trading links and paying a fair price for a product.

\subsection{The Niche-Market Era of Fair Trade}

The niche-market era of fair trade (1990-2000) represented a transition from ideological convictions towards a form of commerce focused on product variety and increased quality (Davies, 2007; Nicholls \& Opal, 2005). Fair trade witnessed improved forms of coordination between producers and distributors; new participants such as fair trade associations, certification bodies (i.e., the Fairtrade Labelling Organization) and marketers arrived. This synchronization placed FT products into larger markets. Profit making was added into the equation of alternative trade. Also, some importance was attributed to the management of key marketing variables (i.e., product, place and price).

Notions of quality economics were adopted in order to provide certification schemes able to guarantee (by means of a standardized label) that the products were manufactured and distributed under proper social conditions. Fair trade coffee was the emblematic commodity that changed the dynamics of the market by means of certification and labelling initiatives. Very soon, these certification and labelling programs expanded to guarantee the quality of a wider array of commodities (i.e., sugar and tea). Fair trade labels redefined the FT supply chain, creating more sophisticated trading routes; they also became the means of signaling and communicating the quality and social attributes behind the products to conscious consumers who did not have the time or the information to inquire about them. Labels helped synthesize and translate this information at the consumer level (Renard, 2005).

In the niche market era, fair trade started to reveal a group of conscious consumers, and corporations became interested in this specific segment. Corporations were motivated by coercive pressures (mainly from advocacy groups and from the media), by strategic positioning (assuring the supply of raw material and the control of purveyors located in the producing south), as well as by increasing market share and profits.

\subsection{The Mass-Market Era of Fair Trade}

An increased shift towards profit-making highlights the passage to the mass-market era of fair trade (2000 onwards). This era is characterized by a deeper market orientation, an appeal to a broader range of consumers in multiple segments, mainstream distribution and the structuring of FT international networks (Davies, 2007). New actors such as multi-national corporations (i.e., Carrefour, Nestlé and Starbucks) arrived. Distinctive forms of coordination emerged (i.e., intra-company labelling and philanthropic efforts), and competing systems to the Fairtrade Labelling Organization (FLO) traditional certification and labelling program also surfaced (i.e. Rainforest Alliance).

In the mass-market era of fair trade, the quality and diversity of products became a strong competitive factor, as well as product standardization and pricing. The notion of quality allowed importers and retailers to adjust the level of grading of some FT merchandises moving them up from basic to premium quality (Davies, 2007).

The appearance of new participant groups (the branders) is a central catalyst of the changes characterizing this era; for these branders, the main objective in FT participation was to assume the leading brand in their specific markets (i.e., Carrefour and Starbucks). The procurement of raw materials, the control over suppliers, price regulation and the improvement of their public image also arise as evident drivers of corporate FT incursion in this era (Renard, 2003).

\subsection{The institutionalized Era of Fair Trade}

Several authors agree upon a fourth hypothetical phase of fair trade (Davies, 2007; Gendron et al., 2009; Lemay et al., 2010). The era of the institutionalization posits fair trade as a demand rather than a supply driven initiative (Davies, 2007). Institutionalization is understood as state, corporate and customer adoption and recognition of FT in different forms. State recognition manifests itself through a series of regulations (at various levels) promoting and facilitating FT. Corporate recognition means embedding FT into the socially responsible efforts of an organization and carrying FT products and brands in the organization's regular offer. Customer recognition refers to the individual taking into consideration FT brands, labels and products while shopping and consuming 
responsibly.

The distinctive point of this era is the universality of FT which can be confirmed by the vast availability and omnipresence of FT products. Universality also has to do with multiple actors operating at different tiers: authorities, companies, adopters, branders, governments, service sector, and socially conscious consumers.

When it comes to products, the institutionalized era of FT considers practically any range of commodities and products manufactured under sustainable standards, and distributed through sustainable value chains (Davies, 2007). In terms of quality, this era observes a return to a wide range of qualities and consistencies in FT products (Davies, 2007). Also, it is foreseen that FT quality can be attained through panoply of certifiers, such as global bodies, national standards and intra-company seals.

In this era, FT can be viewed as a part of the Corporate Social Responsibility (CSR) efforts deployed by multinational corporations currently under great pressure to engage in socially and environmentally responsible practices (Davies, 2007). Organizational activities actuated by strategy in the institutionalized era of fair trade can view FT as the global standard of ethical consumption, as an inspiration for sustainable procurement, as a buffer of risks associated to organizational reputation and as an enhancer of consumer and employee attractiveness (Davies, 2007).

Marketing strategies in the new era of fair trade might focus on sustainability issues. Socially responsible consumers will take into consideration the consequences of the buying decision in terms of environmental preservation, social development or animal welfare, besides the criterion of price and brand ${ }^{\text {Notel }}$. Marketers will also promote self-accreditation and in-house labelling. There will be a place for multi-brand and multi-product marketing in the fair trade domain. Also, we will be in concurrence of marketing efforts tying FT to large events like sporting competitions (i.e., Olympic Games). Marketing specialists would also need to promote and sell FT in association with specific geographical regions (i.e., fair trade cities).

Despite all of these broad avenues of marketing FT in the new institutionalized era, some experts like Davies (2007) identify risks associated to the universality of the movement. One would be the notion of diluted consumption which refers to the difficulty for customers to see the difference in FT products as they become part of an ample offering palette of several sustainable options: green products, eco-efficient, eco-friendly, biological, etc. One last issue relates to the convergence of fair trade practice with conventional market activities.

In summary, an analysis of the literature suggests that the evolution of the FT movement could be organized around four eras, each one characterized by particular organizational and market structures. These eras can be integrated into a comprehensive framework, presented in Table 1.

Further to the development of a framework describing the characteristics of each evolutionary era, we would like to propose an explanation of why this evolution took place. To do so, we used the lens of the Theory of Consumption Values, and explored the evolution of the values sought by consumers when buying FT products.

Table 1. Fair trade (FT) organizational axes and commercial periods of development

\begin{tabular}{|c|c|c|c|c|}
\hline Fair trade eras & $\begin{array}{l}\text { (a) Solidarity era of } \\
\text { FT } \\
(\sim 1970-1990) \\
\text { A campaign period } \\
\text { raising awareness } \\
\text { on social issues }\end{array}$ & $\begin{array}{l}\text { (b) Niche market era of } \\
\text { FT } \\
(\sim 1990-2000) \\
\text { A trade period marked by } \\
\text { the consolidation of } \\
\text { labelling initiatives, } \\
\text { expansion and } \\
\text { distribution }\end{array}$ & $\begin{array}{l}\text { (c) Mass market era of FT } \\
\text { ( 2000-onwards) } \\
\text { A shift towards } \\
\text { commerciality (mainstream) } \\
\text { with great market } \\
\text { orientation }\end{array}$ & $\begin{array}{l}\text { (d) Institutionalized era of FT } \\
\text { (hypothetical) } \\
\text { A phase leading to the } \\
\text { convergence of FT and } \\
\text { conventional market practice }\end{array}$ \\
\hline 1. Actors & $\begin{array}{l}\text { Alternative Trade } \\
\text { Organizations } \\
\text { (ATOs). Social } \\
\text { actors }\end{array}$ & $\begin{array}{l}\text { ATOs, authorities, } \\
\text { companies, early adopters }\end{array}$ & $\begin{array}{l}\text { ATOs, authorities, } \\
\text { companies, adopters, } \\
\text { branders, corporations }\end{array}$ & $\begin{array}{l}\text { Authorities, companies, adopters, } \\
\text { branders, governments, service } \\
\text { sector, conscious consumers }\end{array}$ \\
\hline 2. Focus & $\begin{array}{l}\text { Non profit oriented, } \\
\text { process oriented } \\
\text { Demonstrating } \\
\text { solidarity with } \\
\text { producers }\end{array}$ & $\begin{array}{l}\text { Focus on the product } \\
\text { Focus on the commercial } \\
\text { growth but limited by } \\
\text { ideological issues } \\
\text { Price is not yet the major } \\
\text { issue to traders }\end{array}$ & $\begin{array}{l}\text { Focus on the place } \\
\text { Focus on the quality } \\
\text { Product standardisation and } \\
\text { price become important } \\
\text { issues }\end{array}$ & $\begin{array}{l}\text { Sustainability focus } \\
\text { Universal reach but developing } \\
\text { proximity fair trade (north-north } \\
\text { and south-south) } \\
\text { More a demand than a supply } \\
\text { driven initiative }\end{array}$ \\
\hline
\end{tabular}




\begin{tabular}{|c|c|c|c|c|}
\hline 3. Products & $\begin{array}{l}\text { Ethical products } \\
\text { Crafted items } \\
\text { Coffee ranges }\end{array}$ & $\begin{array}{l}\text { Ethical-quality products } \\
\text { Wider availability of } \\
\text { crafted items } \\
\text { Commodity product line } \\
\text { emerged : coffee, tea, } \\
\text { cocoa, sugar, fruits }\end{array}$ & $\begin{array}{l}\text { Larger variety of } \\
\text { ethical-quality products } \\
\text { Long list of crafted items } \\
\text { (WFTO certified) } \\
\text { Long list of commodities } \\
\text { certified) } \\
\text { A range of over } 4500 \mathrm{FT} \\
\text { products }\end{array}$ & $\begin{array}{l}\text { Ethical-quality-novelty products, } \\
\text { that are socially accepted } \\
\text { Any range of commodities and } \\
\text { manufactured products made and } \\
\text { distributed under sustainability } \\
\text { standards }\end{array}$ \\
\hline 4. Quality & Poor, inconsistent & $\begin{array}{l}\text { Standards for commodity } \\
\text { products, certifications } \\
\text { and labels }\end{array}$ & $\begin{array}{l}\text { Quality as a competitive } \\
\text { factor } \\
\text { FT embedded in quality } \\
\text { economics } \\
\text { Increased level of "grading" } \\
\text { of products }\end{array}$ & $\begin{array}{l}\text { Return to a wide range of qualities } \\
\text { and consistencies } \\
\text { Quality can be attained through a } \\
\text { range of certifiers : global bodies, } \\
\text { national standards, intra-company } \\
\text { labelling and branding }\end{array}$ \\
\hline $\begin{array}{l}5 . \\
\text { Organizational } \\
\text { strategy }\end{array}$ & $\begin{array}{l}\text { Mainly ideological } \\
\text { Raise awareness on } \\
\text { issues of the } \\
\text { developing world }\end{array}$ & $\begin{array}{l}\text { Appeal to groups of } \\
\text { ethical or conscious } \\
\text { consumers }\end{array}$ & $\begin{array}{l}\text { Procurement of raw } \\
\text { materials, price control, } \\
\text { supplier control, image } \\
\text { enhancement }\end{array}$ & $\begin{array}{l}\text { FT is a part of the overall CSR } \\
\text { strategy of the corporation, as the } \\
\text { global standard of ethical } \\
\text { consumption, as an inspiration for } \\
\text { sustainable procurement } \\
\text { FT enhances consumer and } \\
\text { employee attractiveness }\end{array}$ \\
\hline $\begin{array}{l}\text { 6. Marketing } \\
\text { strategy }\end{array}$ & $\begin{array}{l}\text { Dissemination of } \\
\text { information about } \\
\text { poverty and the } \\
\text { crippling nature of } \\
\text { market prices } \\
\text { Solidarity focused } \\
\text { Campaign leaflet } \\
\text { presentations } \\
\text { Marketplace } \\
\text { established at local } \\
\text { fairs and churches }\end{array}$ & $\begin{array}{l}\text { Aiming to create a profit } \\
\text { from a core group of } \\
\text { ethical consumers } \\
\text { Consumer focused } \\
\text { From solidarity to } \\
\text { consciousness } \\
\text { Limited media relations, } \\
\text { promotion and } \\
\text { advertising } \\
\text { FT products reach } \\
\text { supermarkets }\end{array}$ & $\begin{array}{l}\text { Branders added to the } \\
\text { equation seeking to become } \\
\text { the leading brand } \\
\text { Quality focused } \\
\text { Own intra-company } \\
\text { branding } \\
\text { Intensive media relations } \\
\text { Celebrity endorsement } \\
\text { Increased market } \\
\text { segmentation }\end{array}$ & $\begin{array}{l}\text { Sustainability focused. } \\
\text { Responsible consumption } \\
\text { Self accreditation and in-house } \\
\text { labelling } \\
\text { Multi-brand and multi-product } \\
\text { marketing } \\
\text { Marketing for vast events like } \\
\text { sports feats (i.e. Olympic Games) } \\
\text { and for specific geographical } \\
\text { regions (i.e. FT cities) }\end{array}$ \\
\hline $\begin{array}{l}\text { 7. Means of } \\
\text { consumption }\end{array}$ & $\begin{array}{l}\text { Radical } \\
\text { consumption } \\
\text { through solidarity } \\
\text { channels } \\
\text { Developing } \\
\text { solidarity } \\
\text { relationships } \\
\text { between producers, } \\
\text { retailers and } \\
\text { consumers }\end{array}$ & $\begin{array}{l}\text { Pragmatic consumption } \\
\text { While consumer still } \\
\text { bears in mind the } \\
\text { solidarity aspects of the } \\
\text { social movement he } \\
\text { becomes an economic } \\
\text { voter at the store }\end{array}$ & $\begin{array}{l}\text { Individualistic consumption } \\
\text { The consumer disassociates } \\
\text { from the social movement, } \\
\text { he shows lack of collective } \\
\text { focus and he seeks epistemic } \\
\text { value (novelty) in its } \\
\text { purchase }\end{array}$ & $\begin{array}{l}\text { Post-pragmatic or passive } \\
\text { consumption } \\
\text { Consumer has no longer the } \\
\text { alternative: omnipresence of } \\
\text { brands, major brand conversion } \\
\text { and own-supermarket labels fade } \\
\text { away consumer control } \\
\text { Confluence of all types of } \\
\text { consumer activity }\end{array}$ \\
\hline $\begin{array}{l}\text { 8. Consumption } \\
\text { values }\end{array}$ & $\begin{array}{l}\text { Emotional value } \\
\text { Consumer as a } \\
\text { political agent } \\
\text { FT products } \\
\text { arousing solidarity } \\
\text { feelings or affective } \\
\text { states on the } \\
\text { individual }\end{array}$ & $\begin{array}{l}\text { Functional value } \\
\text { Consumer is both a } \\
\text { political and an economic } \\
\text { actor } \\
\text { The alternative form of } \\
\text { consumption acquires } \\
\text { functional value through } \\
\text { the quality attributes } \\
\text { brought by labels }\end{array}$ & $\begin{array}{l}\text { Epistemic value } \\
\text { Consumer depoliticizes from } \\
\text { FT and becomes a mere } \\
\text { economic agent searching } \\
\text { for novelty } \\
\text { The novelty of fair trade } \\
\text { products and its vast } \\
\text { availability appeals to a } \\
\text { broader range of consumers } \\
\text { in multiple segments }\end{array}$ & $\begin{array}{l}\text { Ethical value (with relativism) } \\
\text { Consumer becomes a more } \\
\text { responsible buyer but faces } \\
\text { multiple concerns (economic, } \\
\text { environmental and social } \\
\text { imperatives) } \\
\text { Ethical consumers operating in } \\
\text { heterogeneous groups } \\
\text { Consumer decision making is both } \\
\text { emotive and reflective rather than } \\
\text { just rational }\end{array}$ \\
\hline
\end{tabular}

Sources: Davies (2007); Doherty et al. (2012); Özçağlar-Toulouse et al. (2006). 


\section{The Theory of Consumption Values Perspective}

The Theory of Consumption Values (TCV) proposes a framework of analysis for understanding consumer choice in a large variety of consumption situations. TCV summarizes, parsimoniously, contributions from economics, sociology, anthropology, psychology, marketing and consumer behavior.

The TCV is based on three axiomatic propositions: (1) choice is a function of multiple consumption values (notably functional, conditional, social, emotional and epistemic value); (2) these consumption values make differential contributions in any given choice (although some values may be more salient than others); and (3) these consumption values are independent (Sheth et al., 1991a, 1991b).

The theory was originally presented in 1991, and since then it has been used to explain consumer choice in fields as diverse as higher education (Lai, To, Lung, \& Lai, 2012), teenagers' smoking behavior (Albaum, Baker, Hozier, \& Rogers, 2002), technology adoption (Hedman \& Gimpel, 2010; Turel, Serenko, \& Bontis, 2010) and ethical consumption (Green \& Peloza, 2011). TCV has shown substantial explanatory as well as prescriptive power in more than 200 studies concerning the choice of buying versus not buying, the choice of product type, and the choice of brand type (Sheth et al., 1991a).

Exploratory research in ethical consumption has used TCV to understand how corporate social responsibility activities create value for consumers (Green \& Peloza, 2011). Their results suggest that emotional, social and functional value are the main dimensions of perceived consumer value of CSR activities, and that these value dimensions positively affect marketing outcomes like loyalty and willingness to pay (Green \& Peloza, 2011). Other scholars have explored the internal personal values that ethical consumers express through consumption. A recent exploratory study analyzes the value structure of ethical consumers in general grocery consumption contexts using value frameworks drawn from social psychological research (Shaw, Grehan, Shiu, Hassan, \& Thomson, 2005).

Concerning FT products, another recent review identified fifty-one research articles on individual consumption of FT products. The main theoretical approaches drew from economy (consumer willingness to pay), social psychology (consumer attitudes, information and communication, and consumer values) and sociology (consumer identity) (Andorfer \& Liebe, 2012).

An area that has not been extensively explored is the consumers' value perception of FT products. Insights on this issue have strong and immediate significance for practitioners willing to brand, position and communicate FT product offerings. Understanding what the different sought values are, will allow practitioners to define market segments, refine product lines, position brands and define communication campaigns. To that purpose, TCV provides the ideal framework to analyze consumers' value perception.

In the remaining of this section, we use TCV as a framework to understand the evolution of consumers' value perception associated with the different eras of FT, as well as the evolution of the perceived value of FT products.

\subsection{The Solidarity Era of Fair Trade}

The solidarity era (1970-1990) was strongly driven by ideology. Alternative trading organizations (ATO) slowly started to raise awareness among affluent consumers in the northern hemisphere about the problems, miseries and injustices suffered by southern producers in under-developed countries. The ATOs' message, transmitted almost on a personal basis at community and religious gatherings, was a call to consumer's superior values of solidarity, help and caring for others (Davies, 2007; Doherty et al., 2012); consumers buying FT products could be satisfied with themselves by means of soothing, to some degree, the distress of an unknown producer.

From the consumers' point of view, perhaps a nuance of charity was the mechanism of exchanging a product for their money. The fact of having the product and using it at home, served as a reinforcement of the good deed knowing that they had contributed to the well-being of the producer while supporting his work ethic at the same time.

In TCV, emotional value is the "capacity to arouse feelings or affective states" (Sheth et al., 1991b: 161) and products acquire emotional value when "associated with specific feelings, or when precipitating or perpetuating those feelings" (Sheth et al., 1991b: 161). We, therefore, identify the emotional component of buying FT products as the more salient consumption value in this era. Thus,

$P_{I}$ : In the solidarity era of FT, consumer choice is mainly a function of the emotional value attached to FT products. 


\subsection{The Niche-Market Era of Fair Trade}

The niche-market era of fair trade (1990-2000) witnessed an increase regarding the number and the quality of the products offered at consumers' markets. Many ATOs soon realized that the best advantage they could offer to producers was to increase sales. ATOs started to raise profits through sales, thus sharing the gains with the producers. However, in order to compete with traditional, branded quality products, ATOs had to provide something more than just a call to consumer's superior values of solidarity and social justice. Hence, in a competitive market ATOs had to provide higher quality standards and a label to guarantee the consistency and the quality of the products. The consolidation in 1997 of the Fairtrade Labelling Organizations (FLO) made it easier for both bigger and smaller players to provide this guarantee for fair trade products (Davies, 2007; Moore, 2004). One of the main characteristics of this era was the emergence of companies "focused on providing higher quality products to meet customers' expectations and provide sales volume rather than communicating a particular, political message" (Davies, 2007: 464).

In TCV "an alternative acquires functional value through the possession of salient functional, utilitarian, or physical attributes" (Sheth et al., 1991b: 160). Hence, the most salient value for the customer in this era was the functional value.

$P_{2}$ : In the niche-market era of FT, consumer choice is mainly a function of the functional value attached to FT products.

\subsection{The Mass-Market Era of Fair Trade}

In the mass-market era of fair trade (2000-onwards) the industry structure remains relatively stable, but the number of companies carrying FT products greatly increased. Today, there is a proliferation of independent wholesalers, retailers, as well as service sector organizations (coffee stores, restaurants, airlines, college and university canteens, etc.) offering fair trade products (Davies, 2007). It seems highly fashionable to offer FT products and even big branders (traditionally mass marketers, i.e. Nestlé or Starbucks) have incorporated FT products into their product lines.

This trend towards larger volume and variety of FT products in the big branders' lines is also accompanied by an increase in the quality and the grading of FT products, from basic to premium (Davies, 2007). Branders did this probably to continue offering products with the same level of quality as their traditional lines, but within the trend of fair trade. Through these extensions, it seems that mass marketers are trying to ride on the novelty of the fair trade products, benefiting from its increased profits and market share.

The notion of novelty, larger availability, standard quality and even different grades of quality in FT products also modified the consumer's perspective in this particular era of fair trade. At the same time, consumption desires and motivations progress from functional value to epistemic value. Consumers will not only seek availability, functionality and quality on FT products, they will also be after the novelty and trendy aspects surrounding the purchase.

TCV suggests that epistemic value is "the perceived utility acquired from an alternative's capacity to arouse curiosity, provide novelty, and/or satisfy a desire for knowledge" (Sheth et al., 1991b: 162); we propose, then, than in this era, although customers are still interested in buying quality products, the novelty provided by these (formerly niche) FT products is the most salient value offered by these alternatives. Thus,

\section{$P_{3}:$ In the mass-market era of FT, consumer choice is mainly a function of the epistemic value attached to}

FT products.

\subsection{The Institutionalized Era of Fair Trade}

Scholars have speculated that fair trade products will converge in the global conventional market practice (Davies, 2007; Gendron et al., 2009; Lemay et al., 2010). More companies will continue to expand their product lines offering FT products even if the original principles and philosophy of fair trade become blurred. At the present time, an increasing number of companies are demanding FT standard labels from FLO. Other corporations have decided to offer sustainable products guaranteed by their own intra-company sustainable efforts and their brand prestige (i.e., Tim Horton's' Coffee Partnership) (Tim Horton's, 2012), but without depicting a recognizable fair trade label on its products. In other cases, companies are joining cause-related marketing initiatives, considering them as reasonable alternatives to build customer loyalty and increase sales under the socially responsibility perspective (Docherty \& Hibbert, 2003; Drumwright \& Murphy, 2001).

From a consumer's point of view, our research uncovers two trends while predicting the means of consumption and consumer values in this hypothetical fourth era. The first vision is provided by Doherty et al. (2012) in 
which the new era of Fair Trade takes on post-pragmatic or a passive means of consumption. According to these authors, the omnipresence of brands, major brand conversion and supermarket own-labels will take away control from the consumer. The latter will no longer have the alternative of choosing the FT products. The consumer could get lost in a tide of excessive FT availability topped by panoply of labels. Doherty et al. (2012) also foresee the confluence of all types of consumer activity: radicals, pragmatics, individualistic and passive consumers will all share the same space in the FT marketplace of the future.

A second identified trend is that of the ethical consumer. Ethical consumption evolved from being an expression of a political stand to be a socially accepted and sought behavior. In a study by Shaw et al. (2005) one of their participants manifested that:

...it's very much the in thing to be ethical and aware and it comes across as being intellectual as well (...) therefore, if you are putting Cafédirect in your trolley and driving around with it, then you are saying to other people I'm clever enough to know the difference between this and Nescafé... (190)

In the view of this participant "selective ethical consumption displays to the rest of the society an aspect of one's personality and identity" (Shaw et al., 2005: 190). TCV suggests that products acquire social value through association with positively or negatively stereotyped demographic, socioeconomic and cultural-ethnic characteristics of social groups. Thus,

\section{$P_{4}$ : In the institutionalized era of FT, consumer choice is mainly a function of the social value attached to FT products.}

\section{Discussion}

Why do consumers buy fair trade products? And, how has the consumers' perception of fair trade products evolved over time? Based on a literature review, we interpreted the evolution of FT and organized it into a comprehensive framework of analysis, composed of four evolutionary eras. Following this, building on the Theory of Consumption Values, we proposed that for each of the evolutionary eras of fair trade there is a most salient value in the consumers' choice: in the solidarity era emotional value is the most salient component; in the niche-market era, the functional value is the most salient one; in the mass-market era, it is the epistemic value, and in the institutionalized era it is the social value.

\subsection{Managerial Implications}

We consider that our paper makes two main managerial contributions, one concerning the integrative framework and the second one concerning the identification of the main values sought by the consumers in each era.

Concerning the framework, we delved into the literature and integrated different studies into a conceptual framework. This framework describes, for each era, the focus and goals of the players, the characteristcis of the products, the organizational and marketing strategy of the participating institutions, as well as the key consumption values guiding consumers in their choices. Any manager working in these markets could use this information to evaluate their standing and to help them in improving their decision-making process concerning prospective market actions.

We also mentioned that different markets and geographic regions are at different stages in the development of FT. For example, the UK is probably the most developed market concerning FT products and ethical consumption, while other markets in continental Europe are less advanced, and North American markets are even behind. Accordingly, we took the decision of aligning the eras to the UK market and use them to describe a sequence of eras as explored in the literature. Managers making decisions on different markets can use the framework not just to improve their decision-making processes, but also to predict the future evolution of their markets and make strategic movements in advance.

A second managerial contribution of our paper concerns the identification of the main values sought by the consumers in each era. Although we identified only one salient value characterizing each period of development, TCV states that consumption is a function of multiple consumption values and that each value makes a differential contribution in any given choice situation (Sheth et al., 1991a, 1991b). Accordingly, we find that there are two peculiar characteristics concerning FT consumption that are central to marketing management.

First, we identify an evolution in the consumers' perception of FT products: during the first era, a small core of concerned individuals bought FT products mainly driven by their beliefs. In the following eras the segment of alternative, concerned consumers expanded, and individuals started to ask more from FT products. Being only fair was not enough, and they initially demanded more quality (functional value); later, they asked for novelty and variety (epistemic value) and finally, social acceptance and shared values (social value). 
As time passed both the structure of FT markets and consumers' demands evolved: more sophisticated consumers asked for a more refined consumption experience based on a more complex constellation of values. Hence, at present, we do not suggest that consumers choose FT products only because of their social acceptance in some circles, but rather because they are socially accepted and ethically responsible and have good quality and provide novelty. In this new set of values all of them contribute to the overall perceived value although some of them are more salient than others (Figure 1).

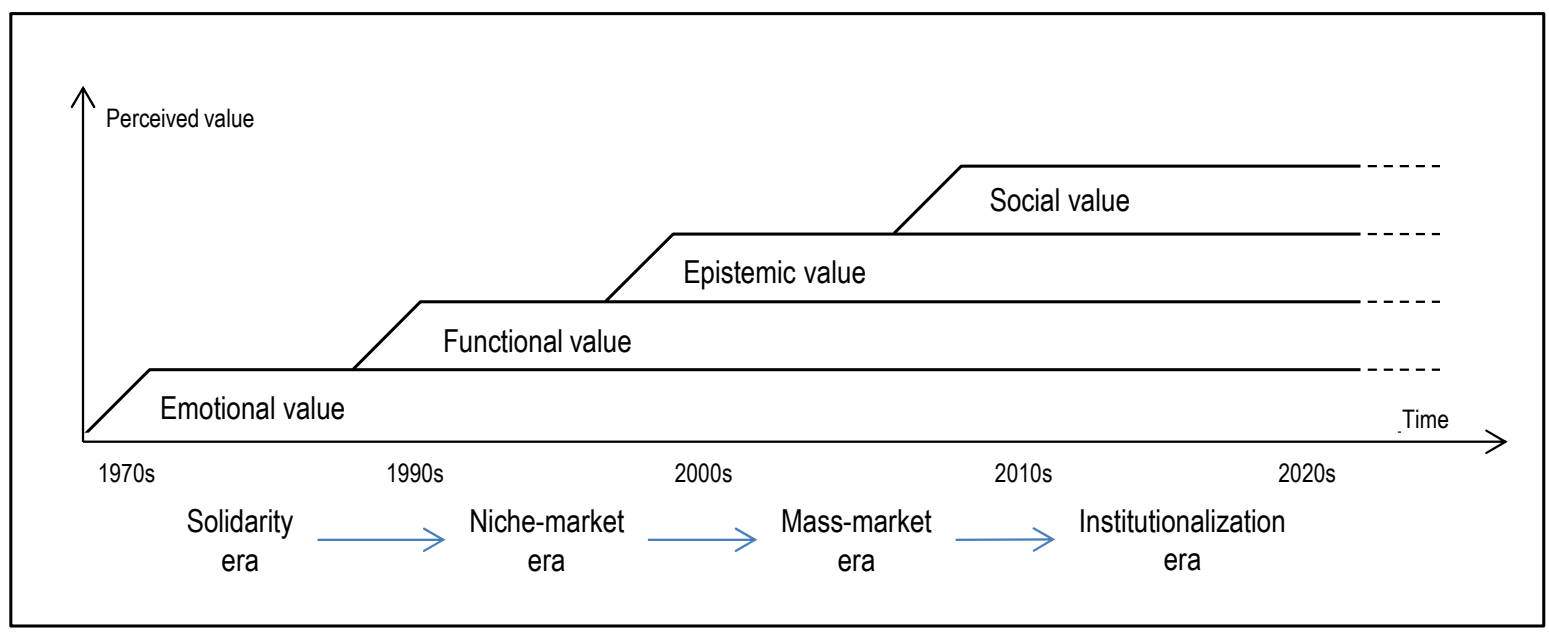

Figure 1. Contribution of consumption values throughout the different eras

Secondly, we note that the FT market grew in such a way that we cannot talk about a typical fair trade consumer anymore. As suggested by Özçağlar-Toulouse et al. (2006), we must start visualizing different segments of ethical consumers operating in heterogeneous groups. Each one of these consumers will bear a mix of preferred consumption values.

A recent exploratory study on ethical consumer decision making by Shaw et al. (2005) illustrates this claim by showing a large heterogeneity of ethical concerns among the sampled individuals: fair trade, local production, health, human rights, organic foods, genetic modification, etc. Additionally, these consumers were guided by a constellation of many different personal values (at least 30 different value meanings) in general consumption activities (Shaw et al., 2005).

Their findings suggest that different segments can be identified based on different ethical concerns (an ethical relativism at the consumer level) and that each segment will identify a different mix of consumption values for the same product offering (with some values more salient than others), thus leading to diversity in product evaluation and consumption. In the institutionalized era of fair trade, a multiplicity of options will probably be offered to different ethical consumers segments willing to express their different stands through consumption.

These two findings are very important to managers making decisions on product lines, branding and positioning. It seems that the demand might go beyond the field of FT products to a broader concept. Lai (1995) suggest that consumers use product constellations to achieve personal values; accordingly, in the present FT market there might be room for different lines of ethical products, each offering different salient values (functional, epistemic, emotional and/or social).

\subsection{Limits and Future Research}

One of the limits of this conceptual article is that our propositions are based on the articulation of secondary data with a theoretical framework (TCV). Empirical data is, therefore, absent. Future research could address this shortcoming by using other research methodologies (exploratory and/or confirmatory) to test the propositions.

Another limit is that most of the research in the evolution of FT is based on single or multiple case studies; most of these case studies focus on the UK market (because the United Kingdom is probably the most matured market of FT products worldwide). Given this situation, we presented our propositions in line with the evolution of this market. Future research could evaluate if other geographical markets of FT present the same patterns of evolution and whether our propositions are applicable to those markets. 


\section{Conclusions}

In summary, based on a review of the most respected authors in the FT literature, we presented the evolution of FT along its evolutive generations, integrating different perspectives into one comprehensive framework.

Thereafter, building on the Theory of Consumption Values we proposed that there has been an evolution in the consumers' perception of FT products. For each one of the fair trade eras identified in the literature, there was a salient value guiding the consumers' choice: emotional value in the solidarity era, functional value in the niche-market era, epistemic value in the mass-market era and social value in the institutionalized era.

TCV suggests, however, that consumption is a function of multiple consumption values and that each value makes a differential contribution in any given choice situation. Accordingly, we proposed that in present markets, although some values might be more salient than others, consumers choose fair trade products because they are socially accepted and ethically responsible and have good quality and provide novelty: in this constellation of values all of them contribute to the overall perceived value.

Finally, we suggest that different segments can be identified based on different ethical concerns and that each segment will identify a different mix of consumption values for the same product offering (with some values more salient than others), thus leading to diversity in product evaluation and consumption.

We opened our discussion section with two questions: why do consumers buy fair trade products and how has consumer's perception of fair trade products evolved over time. Our article suggest that they buy these products looking for a constellation of different values although some are more salient than others for each segment, and that as years passed, consumers evolved and looked for different values.

\section{Acknowledgements}

The first author would like to acknowledge the support received from Dr Bahram Dadgostar, Dean Faculty of Business Administration, Lakehead University, during the preparation of this manuscript.

\section{References}

Albaum, G., Baker, K. G., Hozier, G. C., \& Rogers, R. D. (2002). Smoking behavior, information sources, and consumption values of teenagers: Implications for public policy and other intervention failures. The Journal of Consumer Affairs, 36(1), 50-76, http://dx.doi.org/10.1111/j.1745-6606.2002.tb00420.x

Andorfer, V. A., \& Liebe, U. (2012). Research on Fair Trade Consumption-A Review. Journal of Business Ethics, 106(4), 415-435. http://dx.doi.org/10.1007/s10551-011-1008-5

Carrero, I., Merino, A., Valor, C., Bilbao, P., Labajo, V., \& Díaz, E. (2011). El despertar al consumo responsable: análisis de un proceso de crecimiento, Grupo de Investigación E-SOST, Universidad Pontificia de Comillas. Retrieved

from http://www.upcomillas.es/investigacion/pdf/E-Sost_Consumo\%20responsable_Resumen\%20ejecutivo\%20e spa\%C3\%B1ol.pdf

Carrero, I., Merino, A., Valor, C., Bilbao, P., Labajo, V., \& Díaz, E. (2012). Comprendiendo al consumidor responsable en España. In El Comercio Justo en España 2011, Coordinadora Estatal de Comercio Justo, Madrid. Retrieved from http://comerciojusto.org/wp-content/uploads/2012/09/Informe-completo-20111.pdf

Davies, I. A. (2007). The eras and participants of fair trade: an industry structure-stakeholder perspective on the grow of the fair trade industry. Corporate Governance, 7(4), 455-470. http://dx.doi.org/10.1108/14720700710820533

Docherty, S., \& Hibbert, S. (2003). Examining company experiences of a UK cause-related marketing campaign. International Journal of Nonprofit and Voluntary Sector Marketing, 8(4), 378-389. http://dx.doi.org/10.1002/nvsm.227

Doherty, B., Davies, I. A., \& Tranchell, S. (2012). Where now for fair trade? Business History. http://dx.doi.org/10.1080/00076791.2012.692083

Drumwright, M. E., \& Murphy, P. (2001). Corporate societal marketing. In Bloom, P. N., \& Gundlach, G. T. (Eds.), The Handbook of Marketing and Society (pp. 168-183). Thousand Oaks, CA.

François-Lecompte, A., \& Valette-Florence, P. (2006). Mieux connaître le consommateur socialement responsable. Décisions Marketing, 41, 67-79.

Gendron, C., Bisaillon, V., \& Otero-Rance, A. I. (2009). The institutionalization of fair trade: More than just a degraded form of social action. Journal of Business Ethics, 86(1), 63-79. 
http://dx.doi.org/10.1007/s10551-008-9758-4

Giovannucci, D., \& Koekoek, F. J. (2003). The state of sustainable coffee: a study of twelve major markets. ICO-IISD-WB-UNCTAD-CENICAFÉ, Cali.

Green, T., \& Peloza, J. (2011). How does corporate social responsibility create value for consumers? Journal of Consumer Marketing, 28(1), 48-56. http://dx.doi.org/10.1108/07363761111101949

Hedman, J., \& Gimpel, G. (2010). The adoption of hyped technologies: a qualitative study. Information Technology and Management, 11(4), 161-175. http://dx.doi.org/10.1007/s10799-010-0075-0

Lai, A. W. (1995). Consumer Values, Product Benefits and Consumer Value: A Consumption Behavior Approach. Advances in Consumer Research, 22(1), 381-388.

Lai, L. S. L., To, W. M., Lung, J. W. Y., \& Lai, T. M. (2012). The perceived value of higher education: the voice of Chinese students. Higher Education, 63(3), 271-287. http://dx.doi.org/10.1007/s10734-011-9439-6

Lemay, J. F., Favreau, L., \& Maldidier, C. (2010). Commerce équitable, les défis de la solidarité dans les échanges internationaux. Collection Initiatives, Presses de l'Université du Québec, Sainte-Foy.

Mohr, L. A., Webb, D. J., \& Harris, K. E. (2001). Do consumers expect companies to be socially responsible? The impact of Corporate Social Responsibility on buying behaviour. Journal of Consumer Affairs, 35(1), 45-72. http://dx.doi.org/10.1111/j.1745-6606.2001.tb00102.x

Moore, G. (2004). The fair trade movement: parameters, issues and future research. Journal of Business Ethics, $53(1 / 2), 73-86$.

Nicholls, A., \& Opal, C. (2005). Fair trade: market-driven ethical consumption. London: Sage Publications.

Özçağlar-Toulouse, N., Shiu, E., \& Shaw, D. (2006). In search of fair trade: ethical consumer decision making in France. International Journal of Consumer Studies, 30(5), 502-514.

Renard, M. C. (2003). Fair trade: quality, market and conventions. Journal of Rural Studies, 19(1), 87-96. http://dx.doi.org/10.1016/S0743-0167(02)00051-7

Renard, M. C. (2005). Quality certification, regulation and power in fair trade. Journal of Rural Studies, 21(4), 419-431. http://dx.doi.org/10.1016/j.jrurstud.2005.09.002

Shaw, D., Grehan, E., Shiu, E., Hassan, L., \& Thomson, J. (2005). An Exploration of Values in Ethical Consumer Decision Making. Journal of Consumer Behavior, 4(3), 185-200. http://dx.doi.org/10.1002/cb.3

Sheth, J. N., Newman, B. I., \& Gross, B. L. (1991a). Consumption Values and Market Choices: Theory and Applications. Cincinnati, OH: South-Western Publishing Co.

Sheth, J. N., Newman, B. I., \& Gross, B. L. (1991b). Why We Buy What We Buy: A Theory of Consumption Values. Journal of Business Research, 22(2), 159-170.

Tallontire, A. (2000). Partnerships in fair trade: reflections from a case study of Cafédirect. Development in Practice, 10(2), 166-177. http://dx.doi.org/10.1080/09614520050010205

Tim Hortons. (2012). Tim Hortons Coffee Partnership. Retrieved from http://www.timhortons.com/ca/en/difference/coffee-partnership.html

Turel, O., Serenko, A., \& Bontis, N. (2010). User acceptance of hedonic digital artifacts: A theory of consumption values perspective. Information \& Management, 47(1), 53-59. http://dx.doi.org/10.1016/j.im.2009.10.002

\section{Note}

Note 1. For deeper insight on socially responsible consumption see the works of Carrero, Merino, Valor, Bilbao, Labajo and Diaz (2011, 2012); François-Lecompte and Valette-Florence (2006); Green and Peloza (2011), Mohr, Webb and Harris (2001); Özçağlar-Toulouse, Shiu and Shaw (2006).

\section{Copyrights}

Copyright for this article is retained by the author(s), with first publication rights granted to the journal.

This is an open-access article distributed under the terms and conditions of the Creative Commons Attribution license (http://creativecommons.org/licenses/by/3.0/). 